\title{
Insights into the Management of Overactive Bladder with Transdermal Oxybutynin: A Practical Review
}

This article was published in the following Dove Press journal:

Research and Reports in Urology

\author{
Raúl Vozmediano-Chicharro' \\ Pedro Blasco Hernández $\left(\mathbb{D}^{2}\right.$ \\ Blanca Madurga-Patuel $\mathbb{D}^{3}$ \\ IService of Urology, Hospital \\ Universitario Carlos Haya, Universidad \\ de Málaga, Málaga, Spain; ${ }^{2}$ Service of \\ Urology, Hospital Universitario de Valme, \\ Sevilla, Spain; ${ }^{3}$ Service of Urology, \\ Hospital Universitario Puerta del Mar, \\ Cádiz, Spain
}

\begin{abstract}
Overactive bladder $(\mathrm{OAB})$, clinically defined as urinary urgency, with or without incontinence, generally accompanied by an increase in urinary frequency and nocturia, after any local disease or metabolic disorder that would explain these symptoms have been ruled out, is a highly prevalent condition that affects millions of men and women worldwide. Not only can the symptoms of OAB be very bothersome, but OAB can have significant detrimental effects on many aspects of individuals' lives, representing a particularly impactful health burden to quality of life and productivity. Besides a wide range of conservative treatments, the clinical efficacy of which remains an open issue, antimuscarinics are the mainstay of pharmacotherapy for this condition but anticholinergic troublesome side effects like dry mouth, and the patient's perception of lack of efficacy and poor adherence, are common reasons of abandonment of treatment. An alternative to oral administration treatment, with a lower incidence of dry mouth and other anticholinergic adverse effects, might be attractive to patients and a real treatment option for physicians. Delivery of oxybutynin directly through the skin with oxybutynin transdermal (OXY-TDS) avoids the first-pass hepatic metabolism that occurs with orally administered oxybutynin and prevents the appearance of anticholinergic adverse events. OXY-TDS being equally effective than oral treatment improves adherence, persistence, and patient satisfaction. The aim of this review is to focus on evidence available of the use of OXY-TDS in the management of patients with $\mathrm{OAB}$, and to help clinicians in the challenges involved in the treatment options for patients with this condition.
\end{abstract}

Keywords: antimuscarinics, frequency, urgency, overactive bladder, oxybutynin, transdermal oxybutynin

\section{Background}

Overactive bladder (OAB) defined by urinary urgency with or without urge incontinence, often accompanied by frequency and nocturia ${ }^{1}$ is a prevalent condition both in men and women. In the EPIC study, the largest population-based survey in five countries (Canada, Sweden, Germany, Italy, and the UK), the overall prevalence of OAB was $11.8 \%$, with similar rates in men and women, and increasing with age. ${ }^{2}$ In the 2013, data from 31,763,561 beneficiaries in the Medicare fee-for-service population in the United States, the prevalence of OAB was $7.2 \%$, but projected to increase by $48.8 \%$ from 2013 to $2027 .{ }^{3}$ Other population-based studies have shown prevalences of OAB around $16 \%{ }^{4,5}$ In the EpiLUTS study conducted in the US, UK, and Sweden, the overall prevalence of lower urinary tract symptoms (LUTS) was $24.7 \%$ when symptoms were defined as "often" and $35.6 \%$ when defined as sometimes." 6 OAB with combined urge incontinence and/or LUTS have
Correspondence: Raúl

Vozmediano-Chicharro

Hospital Universitario Carlos Haya,

Universidad de Málaga, Av. de Carlos

Haya, 84, Málaga 29010, Spain

Email vozme@msn.com 
a substantial multidimensional impact on patients (quality of life, work productivity, sexuality, physical and emotional well-being) and economic burden on health-care systems, with important public health and clinical management implications to maximize treatment options and optimize patient outcomes. ${ }^{8}$

The use of anticholinergics has been the mainstay of managing $\mathrm{OAB}$ for years. Anticholinergic agents block postganglionic muscarinic receptors with variable selectivity for different receptor subtypes, decreasing bladder contractility, reducing intravesical pressure, and raising the volume threshold for micturition. ${ }^{9}$ However, because anticholinergic receptors are found throughout the body, the side effects of these drugs are common and widespread. Side effects, including dry mouth, blurry vision, dry eye or constipation associated with oral formulations have been shown to be a primary reason for discontinuing $\mathrm{OAB}$ medications. ${ }^{10}$ In clinical practice, only a minority of patients persist with anticholinergic medication beyond 6 months. Persistence or compliance with pharmacotherapy remains a significant barrier to effectively managing OAB. ${ }^{11}$ These difficulties have led to the development of alternative formulations. Transdermal oxybutynin (OXYTDS) bypasses the first-pass metabolism and reduces the formation of N-desethyloxybutynin (N-DEO), a compound believed to be associated with anticholinergic side effects. ${ }^{12}$ OXY-TDS is a valuable option instead of oral anticholinergics for patients who are at risk or who have experienced dry mouth with oral agents. ${ }^{13,14}$

In this review, we aimed to present the current evidence of OXY-TDS in the management of OAB available in the literature to date, with a focus on relevant data regarding efficacy, safety, adherence, persistence, and patient satisfaction. We also aimed to provide an overview on how OXY-TDS can be integrated into clinical practice to help clinicians towards problems and challenges related to management of patients with $\mathrm{OAB}$ in real-world clinical settings.

\section{OXY-TDS Mechanism of Action and Pharmacokinetics}

Oxybutynin (OXY) is tertiary amine with a twofold mechanism of action: antimuscarinic properties, with selectivity for $\mathrm{M}_{1}$ and $\mathrm{M}_{3}$ receptors, and spasmolytic action on detrusor smooth muscle cells. ${ }^{15-17}$ The salivary glands, in particular, have $\mathrm{M}_{3}$ receptors which account for the high rate of dry mouth experienced by patients treated with oral
OXY. Although OXY has been consistently shown to be superior to placebo in randomized double-blind clinical trials, ${ }^{18,19}$ dry mouth is especially an important side effect limiting its use in clinical practice. OXY-TDS is a matrixtype patch composed of a backing film, an adhesive/drug layer, and release liner (dosage $39 \mathrm{~cm}^{2}$ patch delivering an average dose of $3.9 \mathrm{mg}$ per $24 \mathrm{~h}$ ). Administration of OXYTDS, twice a week, has been licensed for use by the US FDA in 2003, and authorized on June 15, 2004 by the European Medicines Agency. In the EU, OXY-TDS is approved for symptomatic treatment of urge incontinence and/or increased urinary frequency and urgency in patients with $\mathrm{OAB}$.

The OXY is absorbed by the capillary microcirculation of the skin dermis and delivered into the systemic circulation bypassing first-pass metabolism in the liver. Therefore, the conversion of OXY to its main metabolite $\mathrm{N}-\mathrm{DEO}$ is reduced. By contrast, following oral administration, OXY undergoes extensive first-pass metabolism in the liver and an additional portion is metabolized within the lumen of the gastrointestinal tract. Hepatic CYP3A4 cytochrome converts OXY to N-DEO, with N-DEO reaching plasma concentrations 4 to 10 times higher than those of native OXY. ${ }^{20}$ Side effects of OXY, in particular dry mouth, are related to the high affinity of N-DEO to bind muscarinic receptors in the parotid gland. ${ }^{21}$

The OXY-TDS system provides continuous delivery of OXY over 96 hours, and the drug is detectable in plasma after 2 hours following patch application. Steady-state is achieved during the second patch application period. In a study of the pharmacokinetics of OXY-TDS and an extended-release oral OXY, mean plasma concentrations were less variable during OXY-TDS and the ratio of area under the curve was significantly lower as compared with extended-release oral administration. ${ }^{22}$ Mean saliva output was greater during transdermal use compared with extended-release oral OXY, and significantly lower N-DEO concentration during OXY-TDS application was also associated with greater saliva output. ${ }^{22}$ Saliva output is a valid surrogate marker of dry mouth. ${ }^{23}$ In vitro skin flux studies showed that both enantiomers of OXY are absorbed equally across human epidermis. ${ }^{24}$ Also, bioequivalence has been demonstrated for the absorption of OXY with the patch application to the buttock or the abdomen. ${ }^{25}$ In an excellent review of Baldwin and Keating, ${ }^{26}$ extensive data of the pharmacokinetic and pharmacodynamic profile of OXY-TDS has been reported. 


\section{Therapeutic Efficacy Clinical Trials}

In 2001, Davila et $\mathrm{al}^{27}$ reported the results of a Phase II, 6-week multicenter randomized double-blind dose titration study, in which the efficacy and safety of OXY-TDS $(1.3 \mathrm{mg} /$ day) was compared with oral immediate release OXY $(2.5 \mathrm{mg})$ in 74 adult volunteers with urge urinary incontinence. The efficacy of both treatment arms was similar (decrease of daily incontinence episodes, visual analog scale [VAS] assessment for reduction of urinary leakage), but dry mouth occurred in $38 \%$ of patients in the OXY-TDS arm and in $94 \%$ in the OXY group $(P<0.001)$. Of the patients in the OXY-TDS group, a reduction in dry mouth severity compared with previous oral treatment was reported by $67 \%$ of patients and $90 \%$ had no or mild skin erythema.

The therapeutic efficacy of OXY-TDS has been evaluated in two Phase III randomized double-blind trials of the Transdermal Oxybutynin Study Group. ${ }^{28,29}$ In 2002, Dmochowski et $\mathrm{al}^{28}$ published the results of a comparison of OXY-TDS and placebo over 12 weeks followed by an open label extension of 12 weeks in 520 patients with $\mathrm{OAB}$ and urge or mixed urinary incontinence. Statistically significant differences were found in all efficacy variables (number of incontinence episodes per week, average daily urinary frequency, average urinary volume per void), as well as in improvements in the quality of life (Incontinence Impact Questionnaire [IIQ] and Urogenital Distress Inventory [UDI]). ${ }^{28}$ The occurrence of dry mouth was similar in both groups and pruritus in the application site was the most common side effect in the OXY-TDS group. In 2003, Dmochowski et $\mathrm{al}^{29}$ conducted another randomized double-blind, double-dummy clinical trial, in which OXY-TDS and long-acting oral tolterodine (TOLLA) and placebo were compared in 361 patients with OAB and urge and mixed urinary incontinence. OXY-TDS and TOL-LA were effective and comparable treatments, with statistically significant differences in all efficacy variables versus placebo. ${ }^{29}$ The duration of the study was 12 weeks and the efficacy endpoints were the same than in the previous randomized trial. ${ }^{28}$ OXY-TDS improved systemic safety with regard to anticholinergic side effects.

In a combined analysis of the results of these two randomized trials, 241 patients received OXY-TDS $\left(3.9 \mathrm{mg} /\right.$ day) and 244 placebo, ${ }^{30}$ daily urinary incontinence episodes and daily urinary frequency showed a $75 \%$ and $18 \%$ reduction in the OXY-TDS group and a $50 \%$ and $8.7 \%$ reduction in the placebo group, respectively $(P=0.0004$ and $P=0.0023)$. Decreases in incontinence episodes were already observed within the first 2-3 weeks of treatment (at the first evaluation) and were sustained throughout the study. Increases in urinary void volume were $15 \%$ and $3.6 \%$, respectively $(P<0.0001)$. Improvements in health-related quality of life (HRQoL) showed significant differences in the IIQ total score in favor of OXY-TDS, whereas improvements in the UDI questionnaire were similar. Integrated safety outcomes confirmed data of the individual trials.

In a 4-week randomized double-blind study of 96 women with $\geq 3$ month history of OAB treated with OXYTDS (3.9 mg/day) or placebo, five patient-selected goals were established as the primary outcome measure. ${ }^{31}$ There were no significant difference in the mean goal achievement between OXY-TDS and placebo (41.9\% vs $32.2 \%$ ), probably attributed to the small sample size. However, decreases in daily urgency episodes and urge incontinence were significantly greater for women assigned to OXYTDS. Improvements in HRQoL (King's Health Questionnaire) were similar. In a further 12-week randomized double-blind clinical trial with 1530 patients with OAB syndrome, in which OXY-TDS, oral propiverine (20 mg) and placebo were compared, OXY-TDS was noninferior to propiverine and statistically significantly better than placebo in all outcome measures. ${ }^{32}$ The incidence of dry mouth and constipation was higher with propiverine than with the oxybutynin patch or placebo, although site dermatitis was more frequent with the oxybutynin patch. Details of all these trials are shown in Table 1.

\section{Effectiveness of OXY-TDS in Clinical Practice}

The transdermal (TDS) Oxybutynin $\left(\mathrm{Oxytrol}^{(\mathrm{r})}\right)$ in Overactive Bladder (MATRIX) study ${ }^{33}$ was an open-label, prospective, randomized, community-based multicenter cohort study of 2878 adults with OAB enrolled at 327 centers throughout the USA. The duration of the study was 6 months. Study sites were randomized 1:1 within the investigators' medical specialty to provide standard instructions or educational intervention (a packet of educational materials with each month's supply of OXY-TDS). Specific main outcomes included the impact of OXY-TDS on HRQoL, work productivity, and sexual function, but participant-reported perceptions of bladder condition were also evaluated. Using the Patient Perception Bladder Condition 
Table I Salient Data of Relevant Randomized Clinical Trials of OXY-TDS

\begin{tabular}{|c|c|c|c|c|c|}
\hline $\begin{array}{l}\text { Author, } \\
\text { Year } \\
\text { (Reference) }\end{array}$ & Design & Population & $\begin{array}{l}\text { Treatment and } \\
\text { Duration }\end{array}$ & Outcome Measures & Results \\
\hline Davila, $2001^{27}$ & $\begin{array}{l}\text { Randomized } \\
\text { double-blind } \\
\text { dose } \\
\text { titration }\end{array}$ & $\begin{array}{l}74 \text { volunteers with } \\
\text { detrusor instability }\end{array}$ & $\begin{array}{l}\text { OXY-TDS vs oral } \\
\text { OXY and } \\
\text { matching } \\
\text { placebos } \\
6 \text { weeks }\end{array}$ & $\begin{array}{l}\text { Daily incontinence } \\
\text { episodes, visual analog scale } \\
\text { (VAS) for efficacy, dry } \\
\text { mouth symptoms, } \\
\text { multichannel cystometry }\end{array}$ & $\begin{array}{l}\text { Decrease of incontinence episodes } \\
66 \% \text { OXY-TDS vs } 72 \% \text { OXY } \\
(P=0.39) \text {, VAS reduction urinary leak } \\
\text { similar in both groups, dry mouth } \\
\text { occurred in } 38 \% \text { OXY-TDS vs } 95 \% \\
\text { OXY }(P<0.001) \text {, similar } \\
\text { improvements in cystometry } \\
\text { parameters }\end{array}$ \\
\hline $\begin{array}{l}\text { Dmochowski, } \\
2002^{28}\end{array}$ & $\begin{array}{l}\text { Randomized } \\
\text { double-blind }\end{array}$ & $\begin{array}{l}520 \text { patients with } \\
O A B \text { and urge or } \\
\text { mixed urinary } \\
\text { incontinence }\end{array}$ & $\begin{array}{l}\text { OXY-TDS vs } \\
\text { placebo } \\
\text { I2-week double- } \\
\text { blind } \\
\text { I2-week open } \\
\text { label }\end{array}$ & $\begin{array}{l}\text { Incontinence episodes/ } \\
\text { week, average daily urinary } \\
\text { frequency, average urinary } \\
\text { volume/void, quality of life }\end{array}$ & $\begin{array}{l}\text { Median change of incontinence } \\
\text { episodes/week from }-19.0 \text { to }-14.5 \\
(P=0.01) \text {, mean decrease daily } \\
\text { urinary frequency }-2.3 \pm 2.5 \text { vs }-1.7 \\
\pm 3.0 \text { with placebo }(P=0.04) \text {, median } \\
\text { increase urinary volume/void } \\
+24 \mathrm{~mL} \text { vs }+6 \mathrm{~mL} \text { ( } P=0.006) \text {, } \\
\text { substantial improvement in quality of } \\
\text { life, dry mouth incidence was similar }\end{array}$ \\
\hline $\begin{array}{l}\text { Dmochowski, } \\
2003^{29}\end{array}$ & $\begin{array}{l}\text { Randomized } \\
\text { double-blind, } \\
\text { double- } \\
\text { dummy }\end{array}$ & $\begin{array}{l}36 I \text { patients with } \\
O A B \text { and urge or } \\
\text { mixed urinary } \\
\text { incontinence }\end{array}$ & $\begin{array}{l}\text { OXY-TDS and } \\
\text { long-acting oral } \\
\text { tolterodine } \\
\text { (TOL-LA) }(4 \mathrm{mg} / \\
\text { day) vs placebo } \\
\text { I2 weeks }\end{array}$ & $\begin{array}{l}\text { Incontinence episodes/ } \\
\text { week, average daily urinary } \\
\text { frequency, average urinary } \\
\text { volume/void, quality of life }\end{array}$ & $\begin{array}{l}\text { Reductions of incontinence episodes } \\
\text { in OXY-TDS }(-3) \text { and TOL-LA }(-3) \\
\text { vs placebo }(-2)(P<0.05) \text {; average } \\
\text { void volume increase }(24 \text { and } 29 \mathrm{~mL} \\
\text { vs } 5.5 \mathrm{~mL})(P<0.0 \mathrm{I}) \text {; improvement in } \\
\text { quality of life }\end{array}$ \\
\hline $\begin{array}{l}\text { Cartwright, } \\
2010^{31}\end{array}$ & $\begin{array}{l}\text { Randomized } \\
\text { double-blind }\end{array}$ & $\begin{array}{l}96 \text { women with } \geq 3 \\
\text { month history of } \\
\text { OAB, no } \\
\text { restrictions on } \\
\text { urodynamic } \\
\text { diagnosis }\end{array}$ & $\begin{array}{l}\text { OXY-TDS vs } \\
\text { placebo } \\
4 \text { weeks }\end{array}$ & $\begin{array}{l}\text { Five patient-selected goals: } \\
\text { range of OAB symptoms } \\
\text { and quality of life } \\
\text { impairment }\end{array}$ & $\begin{array}{l}\text { Improvement in urgency episodes/ } \\
\text { day }(-\mathrm{I} .23 \text { vs }-0.2 \mathrm{I}, P=0.0 \mathrm{I}) \text { and } \\
\text { urge incontinence episodes/day } \\
(-0.47 \text { vs }-0.23, P=0.04) \text {. No } \\
\text { differences in nocturia. Similar } \\
\text { scores in King's Health } \\
\text { Questionnaire (KHQ) }\end{array}$ \\
\hline $\begin{array}{l}\text { Yamaguchi, } \\
2014^{32}\end{array}$ & $\begin{array}{l}\text { Randomized } \\
\text { double-blind, } \\
\text { double- } \\
\text { dummy }\end{array}$ & $\begin{array}{l}\text { I530 patients with } \\
\text { OAB symptoms } \geq \\
24 \text { weeks, } \geq 8 \\
\text { micturitions daily }\end{array}$ & $\begin{array}{l}\text { OXY-TDS and } \\
\text { oral propiverine } \\
\text { ( } 20 \mathrm{mg} / \text { day) vs } \\
\text { placebo } \\
12 \text { weeks }\end{array}$ & $\begin{array}{l}\text { Micturitions/day, urgency } \\
\text { episodes, urge } \\
\text { incontinence, nocturia, } \\
\text { voided volume/micturition, } \\
\text { quality of life }\end{array}$ & $\begin{array}{l}\text { OXY-TDS vs placebo: micturitions/ } \\
\text { day }-I .89 \text { and }-I .44(P=0.00 \mathrm{I}) \text {; } \\
\text { urgency episodes }-\mathrm{I} .92 \text { and }-\mathrm{I} .5 \mathrm{I} \\
(P=0.006) \text {; urge incontinence }-\mathrm{I} .06 \\
\text { and }-0.88(P=0.0 \mathrm{I}) \text {; voided volume } \\
23.25 \text { and } \mathrm{II} .84 \mathrm{~mL}(P<0.00 \mathrm{I}) \text {; } \\
\text { greater improvement in } \mathrm{KHQ} \text {. OXY- } \\
\text { TDS non-inferior to propiverine }\end{array}$ \\
\hline
\end{tabular}

Abbreviations: KHQ, King's Health Questionnaire; OAB, overactive bladder; OXY, oxybutynin; OXY-TDS, transdermal oxybutynin; TOL-LA, long-acting oral tolterodine; VAS, visual analog scale.

(PPBC), 22.7\% of patients scored less severe OAB symptoms (PPBC score 1, 2 or 3 ) at baseline increasing to $57.5 \%$ at 6 months. ${ }^{33}$ The percentage of patients with more severe OAB symptoms (PPBC score 4, 5 or 6) decreased from $77.3 \%$ to $42.5 \%$. Moreover, at baseline $16.5 \%$ of participants felt that they "always" had enough time to get to the bathroom during the past month, a percentage that almost doubled after 1 month of treatment (33.9\%) and increased to $44.1 \%$ at 6 months. ${ }^{33}$

In 2018, Vozmediano-Chicharro et $\mathrm{al}^{34}$ reported the findings of The Oxybutynin-transdermal in Standard ClinicAl pRactice study (OSCAR study), which was a retrospective 
cohort study conducted in daily practice in three Spanish centers from the same health-care regions in Spain. Data of 105 patients diagnosed with $\mathrm{OAB}$ were reviewed and changes in symptoms of OAB after 12 months of treatment as compared with baseline were evaluated, primarily with a 3-day voiding diary. Significant improvements were observed in urinary frequency $(-2.6$ voids/day, 95\% CI -3.5 to $-1.8, P<0.001)$, number of urgent episodes/day $(-4.7,95 \% \mathrm{CI}-6.1$ to $-3.6, P<0.001)$, and urge incontinence $(-1.9$ episodes/day, $95 \% \mathrm{CI}-2.9$ to $-1.3, P<0.001)$. Improvements in the International Consultation on Incontinence Questionnaire-Short Form (ICIQ-SF) were significant as compared with baseline. In the subanalysis of naïve versus non-naïve patients and patients $<65$ years and $\geq 65$ years, statistically significant differences were not observed. Only $5.7 \%$ of patients reported dry mouth and pruritus and/or erythema at the application site was recorded in $27.6 \%$ of patients.

In relation to HRQoL, which has been consistently included as secondary endpoint in the randomized clinical trials, ${ }^{27-32}$ change in HRQoL using the KHQ instrument from baseline to the end of the study was a primary endpoint of the MATRIX study. ${ }^{35}$ In 2592 evaluable patients, Incontinence Impact, Symptom Severity, and Sleep/Energy were the most impaired domains at baseline. At 6 months, clinically meaningful and statistically significant improvements in 9 of the 10 domains were recorded, with greatest improvements in Incontinence Impact (-13.5), Symptom Severity (-12.4), and Role Limitations (-13.3). These improvements were observed regardless of baseline characteristics, such as men with and without pre-existing prostate problems (benign prostatic hyperplasia), patients who received enhanced education materials, patients aged $<75$ years and those $\geq 75$ years, as well as in a subset of participants aged 85 years or older. ${ }^{33-36}$

The impact of OXY-TDS on work productivity among 1112 working adults (mean age 52.4 years) enrolled in the MATRIX study has been evaluated using the Work Productivity Questionnaire (WPQ). ${ }^{37}$ The WPQ captures four physical or emotional barriers in the past 2 weeks associated with physical tasks, time management (routine and working without breaks), mental (focusing on work without wandering thoughts), and output demands (accomplishment of assigned tasks and/or performing to one's potential). An overall WPQ Index Score is calculated to estimate the overall productivity loss. After treatment with OXY-TDS, significant improvements in all mean scores for all WPQ scales from baseline to the end of the study were found $(P \leq 0.0002)$. The mean overall WPQ Index Score decreased from 8.2 to $5.5(P<0.0001)$, and mean productivity loss scores decreased from $7.7 \%$ to $5.2 \%(P<0.0001)$. It was estimated that for a full-time employee working 40 hours/week, a reduction in productivity loss of $2.5 \%$ is equivalent to a gain of approximately 52 hours/year.

The effect of OXY-TDS on sexual function was also evaluated in the population of the MATRIX study using the KHQ instrument and the Beck Depression Inventory II. ${ }^{38}$ The percentage of subjects who said that they leak during intercourse decreased from $22.8 \%$ to $19.3 \%$. Regarding the effects of $\mathrm{OAB}$ on other domains, such as loss of interest in sex, effect of relationship with partner, effect on sex life, and embarrassment, paired analysis of the percent of subjects with improvement versus those who stayed the same or worsened from baseline to end of study showed significant differences in all domains $(P<0.001)$. The comparison of reductions of recurrent urinary tract infection and bladder pain was also significant $(P<0.001)$. The MATRIX study also demonstrated that complete loss of interest in sex was associated with older age, prolonged OAB symptoms, history of prior OAB therapy, and menopausal status in the women, and with age and duration of OAB symptoms in men.

\section{Safety and Tolerability}

Relevant safety outcomes reported in the randomized double-blind clinical trials and in the OSCAR and MATRIX studies are detailed in Table 2. Findings from safety analyses of patients included in the randomized double-blind trials indicate that OXY-TDS is safe and well tolerated. The most common adverse event was application site reactions (erythema or pruritus) in the OXY-TDS arm as compared with placebo or TOL-LA, although the rate of anticholinergic adverse events experienced with OXYTDS (eg, dry mouth, constipation) was low and not significantly different from placebo. Most cases of local skin reaction were of mild to moderate intensity and resolved with topical corticosteroids or antihistamines. The rate of discontinuation due to erythema was $3.7 \%$ and due to pruritus $3.3 \% .^{30}$ Of note, that none of the patients withdrew from the trials because of dry mouth, a common reason for discontinuation from oral anticholinergic therapy.

In studies carried out in clinical practice conditions (Table 2), OXY-TDS was also well tolerated and safe. In the MATRIX study, ${ }^{33}$ safety analysis was performed in the total population of 2878 patients with OAB who received 
Table 2 Safety Data of OXY-TDS in Randomized Studies and Studies in Daily Practice

\begin{tabular}{|c|c|c|c|c|c|}
\hline $\begin{array}{l}\text { Author, } \\
\text { Year } \\
\text { (Reference) }\end{array}$ & Design & Population & $\begin{array}{l}\text { Treatment and } \\
\text { Duration }\end{array}$ & Adverse Events & $\begin{array}{l}\text { Anticholinergic Adverse } \\
\text { Events }\end{array}$ \\
\hline $\begin{array}{l}\text { Dmochowski, } \\
2002^{28}\end{array}$ & Randomized double-blind & $\begin{array}{l}520 \text { patients with } \\
O A B \text { and urge or } \\
\text { mixed urinary } \\
\text { incontinence }\end{array}$ & $\begin{array}{l}\text { OXY-TDS vs } \\
\text { placebo } \\
\text { I2-week double- } \\
\text { blind } \\
\text { I2-week open label }\end{array}$ & $\begin{array}{l}\text { OXY-TDS vs placebo } \\
\text { Application site reactions: } \\
\text { - Erythema } 5.6 \% \text { vs } 2.3 \% \\
\text { - Pruritus } 16.8 \% \text { vs } 6.1 \% \\
\text { Discontinuation } 10.2 \% \text { dur- } \\
\text { ing the double-blind period } \\
\text { and } 7.3 \% \text { during the open } \\
\text { label phase }\end{array}$ & $\begin{array}{l}\text { OXY-TDS vs placebo } \\
\text { - Dry mouth } 9.6 \% \text { vs } 8.3 \% \\
\text { - Dizziness } 4.0 \% \text { vs } 3.8 \% \\
\text { - Somnolence } 1.6 \% \text { vs } 0.8 \% \\
\text { - Nausea } 1.6 \% \text { vs } 5.3 \% \\
\text { - Constipation } 0.8 \% \text { vs } \\
3.0 \% \\
\text { - Palpitations } 0.8 \% \text { vs } 0 \% \\
\text { - Vision abnormal } 0 \% \text { vs } \\
\text { I.5\% }\end{array}$ \\
\hline $\begin{array}{l}\text { Dmochowski, } \\
2003^{29}\end{array}$ & $\begin{array}{l}\text { Randomized double-blind, } \\
\text { double-dummy }\end{array}$ & $\begin{array}{l}361 \text { patients with } \\
O A B \text { and urge or } \\
\text { mixed urinary } \\
\text { incontinence }\end{array}$ & $\begin{array}{l}\text { OXY-TDS and long- } \\
\text { acting oral } \\
\text { tolterodine (TOL- } \\
\text { LA) ( } 4 \mathrm{mg} / \text { day) vs } \\
\text { placebo } \\
12 \text { weeks }\end{array}$ & $\begin{array}{l}\text { OXY-TDS vs placebo } \\
\text { Application site reactions: } \\
\text { - Erythema } 8.3 \% \text { vs } 1.7 \% \\
\text { - Pruritus } 14.0 \% \text { vs } 4.3 \% \\
\text { Discontinuation } 10.7 \%\end{array}$ & $\begin{array}{l}\text { OXY-TDS vs placebo } \\
\text { - Dry mouth } 4.1 \% \text { vs } 1.7 \% \\
\text { - Constipation } 3.3 \% \text { vs } 0 \% \\
\text { TOL-LA vs placebo: } \\
\text { - Dry mouth } 7.3 \% \text { vs } 1.7 \% \\
\text { - Constipation } 5.7 \% \text { vs } 0 \%\end{array}$ \\
\hline Sand, $2007^{35}$ & $\begin{array}{l}\text { Open-label, prospective, } \\
\text { randomized, community- } \\
\text { based multicenter cohort } \\
\text { study (MATRIX study) }\end{array}$ & $\begin{array}{l}2878 \text { patients with } \\
O A B\end{array}$ & $\begin{array}{l}\text { OXY-TDS } \\
6 \text { months }\end{array}$ & $\begin{array}{l}\text { - Symptomatic adverse } \\
\text { events } 30 \% \text { (mild } 14.7 \% \text {, } \\
\text { moderate } 11.3 \% \text {, severe } \\
4.0 \% \text { ) } \\
\text { - Application site reactions } \\
14.0 \% \\
\text { - Pruritus } 4.9 \% \\
\text { - Erythema } 4.6 \% \\
\text { - Dermatitis } 4.4 \% \\
\text { - Irritation } 3.2 \% \\
\text { - Discontinuation } 16.5 \%\end{array}$ & $\begin{array}{l}\text { - } \text { Dry mouth } 2.6 \% \\
\text { - } \text { Constipation } 1.5 \% \\
\text { - } \text { Nausea } 0.9 \% \\
\text { - } \text { Dizziness } 0.7 \% \\
\text { - } \text { Blurred vision } 0.6 \% \\
\text { - } \text { Dry eye } 0.5 \% \\
\text { - } \text { Somnolence } 0.3 \% \\
\text { - } \text { Palpitations } 0.2 \% \\
\text { Confusion } 0.5 \%\end{array}$ \\
\hline $\begin{array}{l}\text { Cartwright, } \\
2010^{31}\end{array}$ & Randomized double-blind & $\begin{array}{l}96 \text { women with } \geq \\
3 \text { month history of } \\
O A B\end{array}$ & $\begin{array}{l}\text { OXY-TDS vs } \\
\text { placebo } \\
4 \text { weeks }\end{array}$ & $\begin{array}{l}\text { At least one adverse event } \\
41.1 \% \text { (mild } 89.7 \% \text {, moderate } \\
10.2 \% \text { ) } \\
\text { Erythema or pruritus: } \\
\text { - OXY-TDS } 38.2 \% \\
\text { - Placebo } 27.1 \% \\
\text { Discontinuation } 7.3 \%\end{array}$ & $\begin{array}{l}\text { Systemic adverse events (at } \\
\text { least I): } \\
\text { - OXY-TDS } 7 \quad(14.9 \%) \\
\text { patients (dry mouth the } \\
\text { most common) } \\
\text { - Placebo } 6(12.5 \%)\end{array}$ \\
\hline $\begin{array}{l}\text { Yamaguchi, } \\
2014^{32}\end{array}$ & $\begin{array}{l}\text { Randomized double-blind, } \\
\text { double-dummy }\end{array}$ & $\begin{array}{l}1530 \text { patients with } \\
O A B \text { symptoms } \geq \\
24 \text { weeks, } \geq 8 \\
\text { micturitions daily }\end{array}$ & $\begin{array}{l}\text { OXY-TDS and oral } \\
\text { propiverine }(20 \mathrm{mg} / \\
\text { day) vs placebo } \\
12 \text { weeks }\end{array}$ & $\begin{array}{l}\text { - Symptomatic adverse } \\
\text { events (non-application } \\
\text { site) } 32.2 \% \text { OXY-TDS, } \\
41.0 \% \text { propiverine, } 32.0 \% \\
\text { placebo } \\
\text { - Symptomatic application } \\
\text { site events } 40.2 \% \text { OXY- } \\
\text { TDS, } 10.2 \% \text { propiverine, } \\
\text { 8.9\% placebo } \\
\text { - Application site dermatitis } \\
31.8 \% \text { OXY-TDS, } 5.9 \% \\
\text { propiverine, } 5.2 \% \text { placebo }\end{array}$ & $\begin{array}{l}\text { Dry mouth } 6.5 \% \text { OXY- } \\
\text { TDS, } 13.2 \% \text { propiverine, } \\
\text { I.8\% placebo } \\
\text { Constipation } 0.7 \% \text { OXY- } \\
\text { TDS, } 5.0 \% \text { propiverine, } \\
\text { I.0\% placebo }\end{array}$ \\
\hline
\end{tabular}

(Continued) 
Table 2 (Continued).

\begin{tabular}{|c|c|c|c|c|c|}
\hline $\begin{array}{l}\text { Author, } \\
\text { Year } \\
\text { (Reference) }\end{array}$ & Design & Population & $\begin{array}{l}\text { Treatment and } \\
\text { Duration }\end{array}$ & Adverse Events & $\begin{array}{l}\text { Anticholinergic Adverse } \\
\text { Events }\end{array}$ \\
\hline $\begin{array}{l}\text { Vozmediano- } \\
\text { Chicharro, } \\
2018^{34,39}\end{array}$ & $\begin{array}{l}\text { Retrospective cohort study } \\
\text { (OSCAR study) in daily } \\
\text { practice }\end{array}$ & $\begin{array}{l}150 \text { patients with } \\
O A B\end{array}$ & $\begin{array}{l}\text { OXY-TDS } \\
12 \text { months }\end{array}$ & $\begin{array}{l}\text { - Symptomatic adverse } \\
\text { events } 38.1 \% \\
\text { - Symptomatic application } \\
\text { site events } 27.6 \% \text { : pruritus } \\
\text { 15.2\%, erythema } 3.8 \% \text {, } \\
\text { irritated skin } 12.4 \% \\
\text { - Discontinuation } 44.7 \%\end{array}$ & $\begin{array}{ll}\text { - } & \text { Dry mouth } 5.7 \% \\
\text { - } & \text { Constipation } 0.9 \% \\
\text { - Dizziness } 0.9 \% \\
\text { - } \\
\text { - } \\
\text { - Other } 5.7 \%\end{array}$ \\
\hline
\end{tabular}

Abbreviations: OAB, overactive bladder; OXY-TDS, transdermal oxybutynin; TOL-LA, long-acting oral tolterodine.

at least one dose of OXY-TDS. ${ }^{35}$ Adverse events during the 6-month study period occurred in $30 \%$ of the participants but most events were mild or moderate. Application site reactions were experienced by $14 \%$ of patients, with around $4.5 \%$ rates of pruritus, erythema, and dermatitis. Dry mouth occurred in only $2.6 \%$ of cases. The incidence and distribution of adverse events were similar in specific populations of the MATRIX study, such as male patients with prostate conditions ${ }^{33}$ and older adults. ${ }^{36}$ Interestingly, the authors thought that explicit instructions given to subjects to rotate application site each time a patch is applied was the reason for the low incidence of skin reactions observed in older adults, including the subsets of patients aged $\geq 75$ and $\geq 85$ years of age. ${ }^{36}$ In the OSCAR study, local site reactions were the most common (27.6\%), particularly pruritus and irritated skin, in contrast to anticholinergic adverse events which were uncommon (dry mouth $5.7 \%) .{ }^{39}$ Most adverse events were mild or moderate, and only two cases of irritated skin were considered clinically relevant.

A recent network meta-analysis of randomized controlled trials of anticholinergic drug treatment for people with $\mathrm{OAB}$ included 128 studies evaluating several anticholinergic drugs (tolterodine, oxybutynin, trospium, propiverine, solifenacin, darifenacin, imidafenacin and fesoterodine). ${ }^{40}$ Although the effects of anticholinergics for the treatment of $\mathrm{OAB}$ on incontinence episodes and voids per day were clinically similar, OXY-TDS caused less dry mouth than the other treatments, so may be worth considering as the first treatment.

\section{Cognitive Impairment}

Cognitive side effects, such as confusion, changes in memory, blurred vision, or somnolence are related to blockage of $M_{1}$ anticholinergic receptors in the central nervous system (CNS). There is evidence that treatment with anticholinergic drugs increases the risk of developing cognitive impairment and incident dementia, ${ }^{41,42}$ which is particularly a matter of concern in older patients due to a lower number of anticholinergic receptors in the CNS, increased permeability of blood-brain barrier, and modification in drug metabolism secondary to aging, together with the possibility of higher anticholinergic burden due to frequent concomitant medication in this population. OXY-TDS reduces the production of its main metabolite N-DEO, which may account for a significant reduction of anticholinergic adverse events. In an observational retrospective multicenter study, 70 patients with OAB aged $65-80$ years (mean age $71.4 \pm 4.5$ years) treated with OXY-TDS underwent assessment of cognitive function before and after 1 month of treatment. ${ }^{43}$ The Memory Alteration Test (M@T) and the Clock-Drawing Test (CDT) questionnaires were used to assess cognitive function. Differences in the percentages of patients who did not have cognitive impairment before and after starting OXY-TDS treatment were not statistically significant (M@T-test $88.6 \%$ vs $91.4 \%, P=0.727$; CDT test $91.4 \%$ vs $88.6 \%, P=0.687)$. No worsening was observed in the $\mathrm{M} @ \mathrm{~T}$ or CDT scores. Despite the limitation of the small sample size and the retrospective design, this study shows that there is no risk of cognitive impairment in older patients treated with OXY-TDS in the short term. Moreover, there seems to be no risk of cognitive impairment in the long term as shown by the absence of cognitive decline in $51.4 \%$ of patients from the OSCAR study $^{39}$ who completed the Mini-Mental State Examination (MMSE30) at least after 1 year of treatment with OXY-TDS. However, in contrast to the previous 
study of Müller-Arteaga et $\mathrm{al}^{43}$ the population of the OSCAR study was not limited to patients older than 65 years of age. ${ }^{39}$

\section{Persistence, Adherence and Patient Satisfaction}

Persistence of treatment with OXY-TDS assessed by the rate of discontinuation was $7.3 \%$ in the 4-week randomized study of Cartwright et al, ${ }^{31} 10.7 \%$ in the 12 -week randomized trial of Dmochowski et al, ${ }^{29}$ and $16.5 \%$ in the MATRIX study. ${ }^{35}$ The highest rate of discontinuation of $44.8 \%$ was reported in the 12-month OSCAR study, ${ }^{39}$ in which reasons for withdrawal were adverse events (40.9\%), lack of clinical response (38.7\%), and non-compliance with treatment $(9.1 \%)$. In this study, $29.5 \%$ of discontinuations occurred within the 6 months after starting OXY-TDS treatment.

Validated questionnaires to measure adherence to OXYTDS have been used occasionally. The study of MüllerArteaga et $\mathrm{al}^{43}$ aimed to assess short-term changes in cognitive function in 70 elderly patients with $\mathrm{OAB}$ treated with OXY-TDS, is the only study in which adherence was evaluated using the Morisky-Green test. This study shows that $87.1 \%$ of patients stated that they had not forgotten to apply the patch any day, $84.3 \%$ that they changed the patch on the right day, and $92.9 \%$ that they did not stop applying the patch regardless of their state of health. Therefore, there was a high adherence rate as shown by $84.3 \%$ of patients who stated to change the patch on the right day, considering the non-interventional nature of an observational study. ${ }^{43}$

Patient satisfaction with OXY-TDS treatment has been also very high. In the study of Staskin et $\mathrm{al}^{33}$ of 369 male patients of the MATRIX study with underlying prostate conditions, $61.6 \%$ and $71.3 \%$ were "very satisfied" or "satisfied" with treatment and only $8.6 \%$ were "dissatisfied". Also, $60.6 \%$ said that the patch offered significant benefits over previous treatments. In the OSCAR study, satisfaction with treatment was assessed in 58 patients who completed at least 12 months of treatment, ${ }^{39}$ using a 5-item questionnaire specifically designed for the study and a $0-10$ scale for comfortability (10 as the best possible comfort). A total of $92.3 \%$ of patients considered that they felt comfortable with the patch, $87.7 \%$ that OXY-TDS did not or rarely affect daily activities, and $66.7 \%$ that if they could choose between taking a pill and using the patch, they would choose the patch. The mean rate of comfortability for the OXY-TDS patch was $8.7 \pm 1.6$, being 10 the best possible comfort.

\section{Other Aspects}

In spinal cord injury patients with neurogenic detrusor overactivity, OXY-TDS has been shown to be efficacious. In 24 patients included in a multicenter, open-label, dosetitration study, OXY-TDS was tolerated at up to 3 times the standard dose $(11.7 \mathrm{mg} /$ day $)$ and was associated with a statistically significant increase of clean intermittent catheterization (CIC), CIC volume, reflex volume, maximal cystometric bladder capacity, and residual urine volume, whereas detrusor pressure at maximal bladder capacity decreased significantly. The most common adverse events were application site reaction (12.5\% of patients), dry mouth $(8.3 \%)$, and abnormal vision ( $8.3 \%$ ) but no patient discontinued treatment because of an adverse event. ${ }^{44}$ Another study driven by Cartwright et $\mathrm{al}^{45}$ using transdermal and oral oxybutynin in children with neurogenic detrusor overactivity showed that OXY-TDS was a well-tolerated and effective alternative to oral oxybutynin in treating NDO in children who previously tolerated oxybutynin. The study included 57 patients. OXYTDS significantly increased the percentage of leakage-free catheterizations and urine volume and resulted in significant improvement in all measured urodynamic parameters.

Treatment of OAB with OXY-TDS has been evaluated under the economic perspective of the Spanish health care system (2017) using a Markov model for a 5-year time horizon compared to fesoterodine, tolterodine, solifenacin, oxybutynin, trospium chloride, and mirabegron. ${ }^{46}$ After 1 year, OXY-TDS showed greater persistence because of its better risk/benefit balance compared to muscarinic antagonists and mirabegron, and at 5 years led to more QALYs gained and was a highly cost-effective treatment, with an incremental cost-effectiveness ratio well below the thresholds assumed in Spain.

\section{Concluding Remarks}

$\mathrm{OAB}$ is currently a highly prevalent medical condition, usually of chronic course, and expecting to increase given population aging and rising life expectancy. Not only can the symptoms of $\mathrm{OAB}$ be very bothersome, but $\mathrm{OAB}$ has significant detrimental effects on many aspects of the patients, in particular health-related quality of life. Fear of embarrassment leads to social isolation and adaptive behaviors such as avoiding travel or social activities. Oral oxybutynin has been widely used to treat $\mathrm{OAB}$ but untoward anticholinergic side effects provided an impetus for the development of OXYTDS, which reduces side effects and has equal efficacy and tolerability. The $3.9 \mathrm{mg}$ matrix transdermal system is applied 
twice weekly and transports OXY directly into the systemic circulation. The efficacy and safety of OXY-TDS found in phase III clinical trials have been confirmed in cohorts of patients with $\mathrm{OAB}$ attended in daily practice. Besides significant improvements in the constellation of OAB-related symptoms, OXY-TDS has been shown to significantly improve HRQoL, sexual function, marital relationships, as well as to enhance work productivity. The incidence of anticholinergic adverse events with OXY-TDS is similar to placebo, and most common adverse events are mild-tomoderate skin reactions at the application site, improving treatment adherence. Counseling on healthy skin care and appropriate product use can enhance patients' knowledge about OXY-TDS for OAB treatment and reduce the risk of these skin adverse effects.

\section{Acknowledgments}

The authors thank Marta Pulido, MD, PhD, for editing the manuscript and editorial assistance.

\section{Disclosure}

The authors received a grant from Laboratorios Gebro Pharma for this work. Pedro Blasco Hernández reports personal fees from Astellas and Wellspect, outside the submitted work. The authors report no other conflicts of interest related to this work.

\section{References}

1. Abrams P, Cardozo L, Fall M, et al. The standardisation of terminology of lower urinary tract function: report from the standardisation sub-committee of the international continence society. Am J Obstet Gynecol. 2002;187(1):116-126. doi:10.1067/mob.2002.125704

2. Irwin DE, Milsom I, Hunskaar S, et al. Population-based survey of urinary incontinence, overactive bladder, and other lower urinary tract symptoms in five countries: results of the EPIC study. Eur Urol. 2006;50(6):1306-1314. doi:10.1016/j.eururo.2006.09.019

3. Puckrein G, Walker D, Xu L, et al. The prevalence and forecast prevalence of overactive bladder in the medicare population. Clin Med Insights Urol. 2019;12:1-8. doi:10.1177/1179561119847464

4. Stewart WF, Van Rooyen JB, Cundiff GW, et al. Prevalence and burden of overactive bladder in the United States. World J Urol. 2003;20(6):327-336. doi:10.1007/s00345-002-0301-4

5. Milsom I, Abrams P, Cardozo L, Roberts RG, Thüroff J, Wein AJ. How widespread are the symptoms of an overactive bladder and how are they managed? A population-based prevalence study. BJU Int. 2001;87(9):760-766. doi:10.1046/j.1464-410x.2001.02228.x

6. Coyne KS, Sexton CC, Thompson CL, et al. The prevalence of lower urinary tract symptoms (LUTS) in the USA, the UK and Sweden: results from the epidemiology of LUTS (EpiLUTS) study. BJU Int. 2009;104(3):352-360. doi:10.1111/j.1464-410X.2009.08427.x

7. Coyne KS, Sexton CC, Vats V, Thompson C, Kopp ZS, Milsom I. National community prevalence of overactive bladder in the United States stratified by sex and age. Urology. 2011;77(5):1081-1087. doi:10.1016/j.urology.2010.08.039
8. Reynolds WS, Fowke J, Dmochowski R. The burden of overactive bladder on US public health. Curr Bladder Dysfunct Rep. 2016;11 (1):8-13. doi:10.1007/s11884-016-0344-9

9. Wada Y, Yoshida M, Kitani K, et al. Comparison of the effects of various anticholinergic drugs on human isolated urinary bladder. Arch Int Pharmacodyn Ther. 1995;330(1):76-89.

10. Benner JS, Nichol MB, Rovner ES, et al. Patient-reported reasons for discontinuing overactive bladder medication. BJU Int. 2010;105 (9):1276-1282. doi:10.1111/j.1464-410X.2009.09036.x

11. Chancellor MB, Migliaccio-Walle K, Bramley TJ, Chaudhari SL, Corbell C, Globe D. Long-term patterns of use and treatment failure with anticholinergic agents for overactive bladder. Clin Ther. 2013;35 (11):1744-1751. doi:10.1016/j.clinthera.2013.08.017

12. Davila GW. Transdermal oxybutynin in the treatment of overactive bladder. Clin Interv Aging. 2006;1(2):99-105. doi:10.2147/ ciia.2006.1.2.99

13. American Urological Association. Diagnosis and treatment of non-neurogenic overactive bladder (OAB) in adults: an AUA/SUFU guideline (2019) AUA/SUFU guideline: published 2012; amended 2014. Endorsed by the American Urogynecologic Society (AUGS); 2019. Available from: https://www.auanet.org/guidelines/overactivebladder-(oab)-guideline. Accessed February 25, 2020.

14. Buckhard FC, Bosch JLHR, Cruz F, et al. EAU guidelines on urinary incontinence in adults. European Association of Urology; 2018. Available from: https://uroweb.org/wp-content/uploads/EAU-Guidelines-onUrinary-Incontinence-2018-large-text.pdf. Accessed February 25, 2020.

15. Noronha-Blob L, Kachur JF. Enantiomers of oxybutynin: in vitro pharmacological characterization at M1, M2 and M3 muscarinic receptors and in vivo effects on urinary bladder contraction, mydriasis and salivary secretion in guinea pigs. J Pharmacol Exp Ther. 1991;252(2):562-567.

16. Goldenberg MM. An extended-release formulation of oxybutynin chloride for the treatment of overactive urinary bladder. Clin Ther. 1999;21(4):634-642. doi:10.1016/S0149-2918(00)88316-2

17. Chapple CR, Yamanishi T, Chess-Williams R. Muscarinic receptor subtypes and management of the overactive bladder. Urology. 2002;60(5 Suppl 1):82-88. doi:10.1016/S0090-4295(02)01803-4

18. Thüroff JW, Bunke B, Ebner A, et al. Randomized, double-blind, multicenter trial on treatment of frequency, urgency and incontinence related to detrusor hyperactivity: oxybutynin versus propantheline versus placebo. J Urol. 1991;145(4):813-816. doi:10.1016/S00225347(17)38459-8

19. Novara G, Galfano A, Secco S, et al. A systematic review and meta-analysis of randomized controlled trials with antimuscarinic drugs for overactive bladder. Eur Urol. 2008;54(4):740-763. doi:10.1016/j.eururo.2008.06.080

20. Dmochowski RR, Starkman JS, Davila GW. Transdermal drug delivery treatment for overactive bladder. Int Braz J Urol. 2006;32 (5):513-520. doi:10.1590/S1677-55382006000500003

21. Waldeck K, Larsson B, Andersson KE. Comparison of oxybutynin and its active metabolite, N-desethyl-oxybutynin, in the human detrusor and parotid gland. J Urol. 1997;157(3):1093-1097. doi:10.1016/ S0022-5347(01)65148-6

22. Appell RA, Chancellor MB, Zobrist RH, Thomas H, Sanders SW. Pharmacokinetics, metabolism, and saliva output during transdermal and extended-release oral oxybutynin administration in healthy subjects. Mayo Clin Proc. 2003;78(6):696-702. doi:10.4065/78.6.696

23. Sathyan G, Chancellor MB, Gupta SK. Effect of OROS controlled-release delivery on the pharmacokinetics and pharmacodynamics of oxybutynin chloride. Br J Clin Pharmacol. 2001;52 (4):409-417. doi:10.1046/j.0306-5251.2001.01463.x

24. Zobrist RH, Schmid B, Feick A, Quan D, Sanders SW. Pharmacokinetics of the R- and S-enantiomers of oxybutynin and $\mathrm{N}$-desethyloxybutynin following oral and transdermal administration of the racemate in healthy volunteers. Pharm Res. 2001;18 (7):1029-1034. doi:10.1023/A:1010956832113 
25. Zobrist RH, Quan D, Thomas HM, Stanworth S, Sanders SW. Pharmacokinetics and metabolism of transdermal oxybutynin: in vitro and in vivo performance of a novel delivery system. Pharm Res. 2003;20(1):103-109. doi:10.1023/A:1022259011052

26. Baldwin CM, Keating GM. Transdermal oxybutynin. Drugs. 2009;69 (3):327-337. doi:10.2165/00003495-200969030-00008

27. Davila GW, Daugherty CA, Sanders SW. Transdermal oxybutynin study group. A short-term, multicenter, randomized double-blind dose titration study of the efficacy and anticholinergic side effects of transdermal compared to immediate release oral oxybutynin treatment of patients with urge urinary incontinence. J Urol. 2001;166(1):140-145.

28. Dmochowski RR, Davila GW, Zinner NR, et al. Efficacy and safety of transdermal oxybutynin in patients with urge and mixed urinary incontinence. $J$ Urol. 2002;168(2):580-586. doi:10.1016/S00225347(05)64684-8

29. Dmochowski RR, Sand PK, Zinner NR, et al. Comparative efficacy and safety of transdermal oxybutynin and oral tolterodine versus placebo in previously treated patients with urge and mixed urinary incontinence. Urology. 2003;62(2):237-242. doi:10.1016/S00904295(03)00356-X

30. Dmochowski RR, Nitti V, Staskin D, Luber K, Appell R, Davila GW. Transdermal oxybutynin in the treatment of adults with overactive bladder: combined results of two randomized clinical trials. World J Urol. 2005;23(4):263-270. doi:10.1007/s00345-005-0012-8

31. Cartwright R, Srikrishna S, Cardozo L, Robinson D. Patient-selected goals in overactive bladder: a placebo controlled randomized double-blind trial of transdermal oxybutynin for the treatment of urgency and urge incontinence. BJU Int. 2011;107(1):70-76. doi:10.1111/j.1464-410X.2010.09508.x

32. Yamaguchi O, Uchida E, Higo N, et al. Efficacy and safety of once-daily oxybutynin patch versus placebo and propiverine in Japanese patients with overactive bladder: a randomized double-blind trial. Int J Urol. 2014;21(6):586-593. doi:10.1111/iju.12372

33. Staskin DR, Rosenberg MT, Dahl NV, Polishuk PV, Zinner NR. Effects of oxybutynin transdermal system on health-related quality of life and safety in men with overactive bladder and prostate conditions. Int J Clin Pract. 2008;62(1):27-38. doi:10.1111/j.1742-1241.2007.01625.x

34. Vozmediano-Chicharro R, Madurga B, Blasco P. Efficacy of transdermal oxybutynin in the treatment of overactive bladder syndrome: does it make sense using it in 2017? Adv Urol. 2018;2018:6782736. doi: $10.1155 / 2018 / 6782736$

35. Sand P, Zinner N, Newman D, et al. Oxybutynin transdermal system improves the quality of life in adults with overactive bladder: a multicentre, community-based, randomized study. BJU Int. 2007;99(4):836-844. doi:10.1111/j.1464-410X.2006.06658.x
36. Newman DK. The MATRIX study: evaluating the data in older adults. Director. 2008;16(2):21-24.

37. Pizzi LT, Talati A, Gemmen E, Dahl NV, Bunz TJ, Sand PK. Impact of transdermal oxybutynin on work productivity in patients with overactive bladder: results from the MATRIX study. Pharmacoeconomics. 2009;27 (4):329-339. doi:10.2165/00019053-200927040-00005

38. Sand PK, Goldberg RP, Dmochowski RR, McIlwain M, Dahl NV. The impact of the overactive bladder syndrome on sexual function: a preliminary report from the multicenter assessment of transdermal therapy in overactive bladder with oxybutynin trial. Am J Obstet Gynecol. 2006;195(6):1730-1735. doi:10.1016/j.ajog. 2006.08.013

39. Vozmediano-Chicharro R, Blasco Hernández P, Madurga-Patuel B. Tolerabilidad, persistencia y satisfacción. Estudio de cohortes retrospectivas realizado en condiciones de práctica clínica en pacientes con síndrome de vejiga hiperactiva tratados con oxibutinina transdérmica. Estudio OSCAR. Arch Esp Urol. 2017;70(6):561-569.

40. Herbison P, McKenzie JE. Which anticholinergic is best for people with overactive bladders? A network meta-analysis. Neurourol Urodyn. 2019;38(2):525-534. doi:10.1002/nau.23893

41. Coupland CAC, Hill T, Dening T, Morriss R, Moore M, HippisleyCox J. Anticholinergic drug exposure and the risk of dementia: a nested case-control study. JAMA Intern Med. 2019;179(8):1084. doi:10.1001/jamainternmed.2019.0677

42. Richardson K, Fox C, Maidment I, et al. Anticholinergic drugs and risk of dementia: case-control study. BMJ. 2018;361:k1315. doi:10.1136/bmj.k1315

43. Müller-Arteaga C, Batista-Miranda JE, Zubiaur Libano C, et al. Cognitive function assessment in elderly patients with overactive bladder treated with transdermal oxybutynin. Actas Urol Esp. 2019;43(3):143-150. doi:10.1016/j.acuro.2018.07.005

44. Kennelly MJ, Lemack GE, Foote JE, Trop CS. Efficacy and safety of oxybutynin transdermal system in spinal cord injury patients with neurogenic detrusor overactivity and incontinence: an open-label, dose-titration study. Urology. 2009;74(4):741-745. doi:10.1016/j. urology.2009.05.008

45. Cartwright PC, Coplen DE, Kogan BA, Volinn W, Finan E, Hoel G. Efficacy and safety of transdermal and oral oxybutynin in children with neurogenic detrusor overactivity. $J$ Urol. 2009;182 (4):1548-1554. doi:10.1016/j.juro.2009.06.058

46. Crespo C, Blasco P, Guigini M, Galván J. Clinical and economic evaluation of transdermal oxybutynin in the treatment of overactive bladder in Spain. JHEOR. 2018;5(2):194-205. doi:10.36469/9811

\section{Publish your work in this journal}

Research and Reports in Urology is an international, peer-reviewed, open access journal publishing original research, reports, editorials, reviews and commentaries on all aspects of adult and pediatric urology in the clinic and laboratory including the following topics: Pathology, pathophysiology of urological disease; Investigation and treatment of urological disease; Pharmacology of drugs used for the treatment of urological disease. The manuscript management system is completely online and includes a very quick and fair peer-review system, which is all easy to use. Visit http://www.dovepress.com/ testimonials.php to read real quotes from published authors. 